\author{
І.Ю. Юзова ${ }^{1}$, П. Пацек ${ }^{2}$ \\ ${ }^{1}$ Харківський національний університет Повітряних Сил ім. І. Кожедуба, Харків \\ ${ }^{2}$ Академія військового мистеитвва, Варшава
}

\title{
ІНФОРМАЦІЙНО-ПСИХОЛОГІЧНИЙ ВПЛИВ ПРОТИВНИКА ТА ПРОТИДІЯ ЙОМУ В УМОВАХ ВЕДЕННЯ ГІБРИДНИХ ВІЙН
}

В статті встановлено, щзо надзвичайно важливого значення набувають проблеми захисту особового складу Збройних Сил Украӥни та населення від негативного інформаційно-психологічного впливу противника. Метою статті є проведення аналізу наявних проблеми захисту особового складу Збройних Сил Украӥни від негативного інформачійно-психологічного впливу противника та розробка рекомендацій щчодо підвищення рівня протидії інформаційно-психологічному впливу противника в умовах ведення гібридних війн. Встановлено, щуо для опору, стримування та захисту як населення України так і особового складу Збройних Сил від негативного інформаційно-психологічного впливу необхідно мати чітке розуміння природи й характеру ицього конфлікту. Наведено сутність, засоби, види та способи інформаційно-психологічного впливу. Розглянуті основні складові завдання захисту військ (сил) від інформаційно-психологічного впливу супротивника.

Ключові слова: гібридна війна, інформаційна війна, противник, інформаційно-психологічний вплив, морально-психологічне забезпечення.

\section{Вступ}

Постановка проблеми. Військово-політичні конфлікти кінця XX - початку XXI ст. демонструють зміну підходів до розуміння та ведення нового типу війни [1]. Інформаційні технології не тільки надали багато можливостей для обміну інформацією, але й створили можливості для ефективного здійснення інформаційно-психологічного впливу (IПВ).

IПВ $є$ сутністю психологічних операцій, тому що $є$ способом їх проведення

Однією з характерних тенденцій, яка склалася в сучасних умовах, не тільки в Україні, а й у світі в цілому, - це випереджальний розвиток форм, способів, технологій і методик впливу на свідомість (підсвідомість) і психічний стан людини в порівнянні з організацією протидії негативним психологічним впливам, інформаційно-психологічним захистом особистості військовослужбовця, суспільства в цілому. Особливо надзвичайно важливого значення набувають проблеми захисту особового складу Збройних Сил (3С) України від негативного ІПВ противника [2].

Це обумовлюється тим, що спостерігається активне впровадження і розробка у військовій сфері різноманітних методів, способів, форм і технологій ІПВ на масову, індивідуальну і групову свідомість. Російсько-український конфлікт, який розпочався у 2014 році на сході України яскраво демонструє весь арсенал сучасних «гібридних війн» та показує негативний психологічний вплив противника в умовах ведення такої гібридної війни [3].

Цей вплив є комплексом спеціально спланованих та підготовлених дій, акцій, операцій впливу на цивільну та військову інформаційну інфраструктури, на індивідуальну або суспільну свідомість, моральнопсихологічний стан (МПС) особового складу військ (сил) та населення противника для досягнення воєнних, політичних, економічних та психологічних цілей [4]. Для стримування, опору й захисту як особового складу 3С України так і населення від негативного IПВ необхідно мати чітке розуміння характеру цього конфлікту та природи такого конфлікту.

Аналіз останніх досліджень і публікацій. За останні роки опубліковано ряд змістовних аналітичних досліджень вітчизняних і іноземних експертів, де розглядаються цілі, механізми, технології і засоби російської гібридної агресії в Україні та Європі [5-6]. В науковій літературі приділено значну увагу аналізу маніпулюванню свідомістю та стратегій впливу за допомогою засобів масової комунікації [3-4]. Під час опрацювання наукової літератури значну увагу було приділено з'ясуванню механізмів та засобів, які використовуються для здійснення психологічного впливу на військовослужбовців в зоні проведення операції Об'єднаних Сил (ООС), на населення окупованих Росією Донецької та Луганської областей, автономної республіки Крим та населення України в цілому [7-10].

Великий внесок до теоретичних основ ведення інформаційно-психологічного впливу зробили вітчизняні дослідники [9-12, 16-17]. Багато дослідників продовжують свою роботу за досвідом ООС [8; 10; 12].

Мета статті - проаналізувати наявні проблеми захисту особового складу Збройних Сил України та населення від негативного інформаційнопсихологічного впливу противника та розробити 
методичні рекомендації щодо підвищення рівня протидії інформаційно-психологічному впливу противника в умовах ведення гібридних війн.

\section{Виклад основного матеріалу}

Для здійснення ІПВ на противника під час інформаційно-психологічних операцій використовуються різноманітні засоби, такі як інтернет-джерела, засоби масової інформації, різноманітна аудіо та відеопродукція, друковані матеріали й спеціально підібрані та підготовлені люди, які здійснюють ІПВ особисто спілкуючись 3 людьми тощо.

Особлива увага приділяється впливовим політичним лідерам, журналістам, представникам суспільства та військовослужбовцям всіх категорій.

Розглядаючи IПВ як загрозу маємо на увазі негативні наслідки його реалізації. Негативні наслідки можуть проявлятись у відношенні особистості до держави та у руйнуванні цілісності самої особистості [12].

На особовий склад ЗС України постійно здійснюється ІПВ з метою формування, підтримання у їх свідомості визначених соціальних ідей, поглядів, уявлень, переконань, негативних емоцій і почуттів, мотивів недовіри та незадоволення діями свого політичного і військового керівництва, усвідомлення свого складного, несприятливого стану, загрози благополуччю і життю, введення їх в оману та схилення до співробітництва, планомірна трансформація їх свідомості та поведінки для сприяння реалізації цілей і завдань військової акції (операції, кампанії).

Вчені психологи вважають, що навіть при десяти відсотковій ефективності застосування IПВ на людину викликається панічний стан навіть у добре організованому колективі [11].

Таким чином, об'єктом ІПВ виступає індивідуальна і масова свідомість. Ми піддаємось різного роду маніпулятивним впливам, інформаційним за своєю природою, результати яких загрожують нашому фізичному і психічному здоров'ю. Він здійснюється як правило на емоційну сферу свідомості. Також важливою особливістю ІПВ на індивідуальну свідомість $є$ те, що ми не помічаємо і не усвідомлюємо коли опиняємось у ситуації дезінформованості, недовіри, страху, сильних нервових потрясінь, стресу саме внаслідок дії на нас засобів масової інформації, засобів ІПВ.

Особовий склад підрозділів 3С України в певній мірі перебуває у ізоляції від зовнішнього світу, воїни так би мовити випадають із соціального середовища (особливо особовий склад який проходить службу в зоні ООС) і відповідно не мають змоги перевірити достовірність фактів отриманих з різноманітних джерел. Наповнюючи потрібним змістом повідомлення, що передаються різноманітними комунікаційними потоками, можливо подавати не лише знання про навколишню середовище, але й формувати поведінкові та емоційні стереотипи, внутрі- шню картину світу як рядового так і офіцерського складу, своєрідні когнітивно-поведінкової матриці, за допомогою яких й відбувається орієнтація в світі, формується світогляд [14]. Тобто відбувається зміна установок особистості. Це особливо необхідно врахувати при підготовці особового складу, при формуванні та розвитку системи захисту від негативного ІПВ, спрямованої на формування в них психологічної стійкості та готовності до інформаційних викликів сьогодення.

Інформаційно-психологічний вплив являє собою цілеспрямоване розроблення і поширення спеціальної актуальної інформації, здатної безпосередньо або непрямо впливати на суспільну свідомість, психологію і поведінку населення, військовослужбовців. При цьому інформація психологічного i пропагандистського типу може бути не тільки усного, друкованого, письмового, аудіо і візуального походження, але й екстрасенсорного, телепатичного й іншого типу, розрахована, насамперед, на підсвідомість реципієнта впливу.

Можна виділити наступні види інформаційнопсихологічного впливу [15-16]:

- нейролінгвістичний;

- психоаналітичний (психокорекційний);

- психогенний;

- психотропний;

- психотропний.

Нейролінгвістичний вплив - вид психологічного впливу, що припускає використання спеціальних прийомів, спрямованих на створення позитивної мотивації, психологічної корекції внутрішніх джерел поведінки й світогляду особистості людини [7].

Психогенний вплив - це психічний або фізичний вплив подій або явищ на мозок, свідомість людини. При цьому спостерігається порушення вищої нервової діяльності, а саме з'являється відчуття паніки й страху, людина перестає раціонально мислити.

Психоаналітичний (психокорекційний) вплив $є$ вивченням (аналіз) підсвідомості людини й впливом на нього шляхом, що виключає опір на рівні свідомості (здійснюється в стані гіпнотичного сну).

Психотропний вплив - це вплив на мозок і поведінку особистості шляхом введення в іiі організм різних препаратів, засвоєння яких відбивається на іiі вищій нервовій діяльності (у тому числі фармацевтичних препаратів, запахів) [15].

Психотронний вплив - вплив, що може здійснюватися за допомогою передачі енергії мислення через позачуттєве сприйняття і яке охоплює опосередковане свідомістю і процесами сприйняття дистантної взаємодії між навколишнім середовищем та живими організмами [7].

Основними інструментами стратегічного дезінформування є засоби масової інформації, такі як телебачення, радіо, газети та журнали. 
Також способом психологічного впливу $є$ поширення чуток. Поширення чуток - один із найбільш ефективних способів поширення інформації при ІПВ, заснованому на збільшенні групової сугестивності під час впливу [14].

Події осені 2015 р. показали, наскільки ефективними може бути кіберзброя, застосована проти об’єктів критичної інфраструктури, зокрема й тих, що перебувають у приватній власності.

Інтернет і соціальні мережі надали широкі можливості для поширення та розуміння у спрощеному та доступному вигляді (меми) необхідної інформації. I в цьому контексті слід відзначити незначну кількість досліджень у галузі аналізу новітніх технологій ІПВ, зокрема застосування мемів і меметичної зброї в «гібридній» війні.

Особливістю російсько-української війни стало ефективне використання меметичної зброї. Річард Докінз наголошував, що прикладами мемів можуть слугувати ідеї, модні слова чи вислови, рекламні слогани та анекдоти, мелодії або навіть окремі елементи архітектури. Меми передаються від людини до людини за допомогою імітації. Аналіз ефективності застосування цієї технології вимагає розуміння самого поняття «мем» [4].

«Меми» можуть впроваджуватися в нашу свідомість через когнітивний дисонанс. Вони використовується в технологіях пропаганди та реклами: коли інформація повторюється багато разів. Із часом ці меседжі засвоюються свідомістю та стають переконаннями чи постулатами. Меми: «укропи», «колоради», «Крим наш», «ввічливі люди», «ватники», «майдануті», «бандерлоги», «свідоміти», «кіборги» стали елементами ментальної зброї та вплинули на формування світоглядних позицій протидіючих сторін. У формуванні пропагандистського дискурсу російські фахівці інформаційної війни почали активно застосовувати меметичні технології через соціальні медіа. А. Чен, журналіст The New York Times провів дослідження і довів наявність російських центрів по роботі iз соціальними медіа на предмет поширення окремих мемів. Семантичне поле було заповнене тезами «зрада», «нас зливають», «все пропало» тощо. Метою було посилення панічних настроїв та підвищення рівня конфліктності серед населення.

Меметична зброя поступово стає інструментом інформаційної протидії українських силових структур, про що свідчить, зокрема, розробка мему «про Миколу» [13]. Використання меметичної зброї може стати одним з ефективних засобів протидії російській інформаційній експансії. Аналіз поширених українських мемів (наприклад: «ватнік»; «колорад») показав свій вплив на семантичне поле Росії та реакцію російських владних структур.

Зміст та основні завдання захисту особового складу від негативного ІПВ включили в себе інфор- маційно-пропагандистське та психологічне забезпечення, проте постійний інформаційний вплив противника визначає першочерговість завдань захисту від нього.

Аналізуючи та порівнюючи завдання захисту особового складу від негативного ІПВ противника та завдання інформаційно-пропагандистського забезпечення можна стверджувати що вони є спорідненими та полягають як правило у зборі інформації, iї оцінці та прогнозуванні обстановки, організації та проведенні пропагандистської (контрпропагандистської), ідеологічної та інформаційно-роз'яснювальної роботи з особовим складом військ (сил).

Порівняння завдань захисту особового складу від негативного ІПВ та психологічного супроводження визначає більш вузький спектр завдань психологічного забезпечення у захисті особового складу від негативного IПВ. А саме: безперервний і безпосередній аналіз та вивчення динаміки МПС своїх військ й аналіз та вивчення впливу психологічних чинників бойових дій на поведінку та МПС особового складу, їх вимог до емоційно-вольових та психофізіологічних якостей військовослужбовців; підтримку і розвиток у військовослужбовців установки на безумовне виконання бойових завдань; виявлення осіб з нервовопсихічною нестійкістю та вжиття психопрофілактичних, психокорекційних заходів; прогнозування та розрахунок можливих бойових психогенних втрат особового складу; підтримку постійної психічної активності під час бою, усунення впливу його негативних стрес-факторів, відновлення психічної рівноваги, стійкості та оперативне усунення надмірної психічної напруги, здійснення антистресових заходів, адаптацію військовослужбовців до конкретних бойових умов діяльності; здійснення контролю за ступенем стомленості, психічної та психофізіологічної пригніченості особового складу [15]. Таким чином психологічне забезпечення в умовах гібридної війни може розглядатись у інформаційній площині, як системоутворюючий процес захисту від ІПВ тактичного рівня, за допомогою теорій масової комунікації, зв’язку та стресостійкості.

Концепція МПЗ підготовки та ведення операцій та бойових дій ЗС України визначає, що захист військ (сил) від ІПВ противника - це комплекс узгоджених за місцем, часом та цілями заходів, що проводяться органами військового та державного управління усіх рівнів, штабами, командуючими, командирами, начальниками, офіцерами структур 3 МПЗ у воєнний та мирний часи 3 метою прогнозування, запобігання та зриву ІПВ противника, нейтралізації і усунення його наслідків, намагань дезінформувати, деморалізувати особовий склад та дезорганізувати його діяльність [6].

Вирішення проблеми захисту військ (сил) від IПВ противника в сучасних умовах - завдання над- 
звичайно складне, особливо якщо брати до уваги складну суспільно-політичну і соціально-економічну обстановку в державі, а також негативні тенденції, які мають місце в армії. Тому при організації протидії ІПВ противника потрібно враховувати багато різноманітних факторів, а також проводити активну випереджувальну контрпропагандистську роботу. Вона включає комплекс заходів, які спрямовані на захист певної системи світоглядних стереотипів, настанов, орієнтирів, на основі яких грунтується високий МПС військ та здатність до опору агресору.

Захист військ (сил) від ІПВ противника $є$ комплексом погоджених заходів за місцем, часом та цілями, що проводяться у воєнний та мирний часи органами військового та державного управління усіх рівнів, командуючими, командирами, штабами, органами МПЗ з метою запобігання, зриву, нейтралізації і усунення наслідків негативного IПВ противника населення країни та на особовий склад військ [6].

У своїй структурі, захист військ від негативного ІПВ противника має такі етапи: прогнозування, запобігання, зрив та ліквідація наслідків його дій.

На етапі аналізу та прогнозування IПВ заступник командира з МПЗ займається виявленням особливостей і тенденцій розвитку інформаційної та морально-психологічної обстановки на арені воєнних дій; виявленням наявних сил, засобів, способів і прийомів, можливих рубежів і районів, особливостей змісту проведення противником IПсО; виявленням активності і спрямованості ворожих інформаційних потоків та комунікацій, можливих об'єктів і каналів потенційного негативного IПВ на війська (сили). На цьому етапі він повинен з'ясувати можливий рівень деморалізації і психогенних втрат особового складу від ІПВ противника та оцінити ступінь уразливості своїх військ (сил); з'ясувати слабкі місця противника у проведенні інформаційно-психологічних дій.

На етапі запобігання ІПВ противника робота заступника командира підрозділу 3 моральнопсихологічного забезпечення спрямована на своєчасне визначення початку інформаційнопсихологічних акцій і операцій противника; на проведення безперервного й психологічно доцільного суспільно-політичного та бойового інформування особового складу, роз'яснення йому цілей і завдань ведення противником підривних дій; перекриття або встановлення повного контролю над каналами ІПВ противника; виявлення психічно нестійких військовослужбовців, що піддалися ворожому впливу, та проводити психокорекційну роботу 3 ними. Він повинен ознайомити військовослужбовців 3 прийомами й методами IПВ, що використовує противник та як вони впливають на їхню свідомість, який ефект викликають. Брати учать у проведенні розвідки, придушенні та знищенні сил і засобів психологічних операцій противника.
Одним 3 найважливіших завдань у роботі заступника командира підрозділу з МПЗ є проведення заходів, що спрямовані на виховання в особового складу переконань у справедливості боротьби, вірності присязі, віри в командирів та начальників, упевненості в силі і надійності власної зброї, виховання ненависті до ворога і віри в перемогу. А також він повинен працювати над постійним нарощуванням матеріально-технічної бази ІПВ на свої війська і населення.

На етапі зриву ІПВ противника заступник командира підрозділу з МПЗ у взаємодії з командирами начальниками органів військового управління, командирами артилерійських підрозділів, підрозділів радіоелектронної боротьби, посадовими особами Служби безпеки України, Міністерства внутрішніх справ проводить розвідку, придушення або знищення сил і засобів ведення противником інформаційно-психологічної боротьби; займається оперативним збором, аналізом i знищенням сил та засобів психологічних операцій противника. Важливим завданням цього етапу, яке стоїть перед заступником з морально-психологічного забезпечення, є вчасне проведення роботи з припинення панічних настроїв, поширення чуток, здійснення ізоляції та проведення профілактичної роботи з військовослужбовцями, що піддалися ІПВ противника (деморалізації, дезінформації). Він постійно здійснює моніторинг МПС особового складу, проводить виховну роботу у разі його зміни; інформує особового склад підрозділу про застосування противником сил і засобів інформаційно-психологічної боротьби й способи протидії їм. Проводить роботу щодо запобігання поширення серед військовослужбовців та населення антидержавних і анти-армійських матеріалів, іншої ворожої інформації.

Під час ліквідації наслідків ІПВ противника заступник командира з МПЗ займається виявленням й ізоляцією підрозділів і військовослужбовців, що зазнали деморалізації, та надає їм психологічну допомогу. Він постійно працює над припиненням панічних настроїв, ворожих слухів, здійснює профілактику фобій у військовослужбовців; виявляє та усуває причини, що викликали психогенні втрати та усуває їх. Важливим напрямком його діяльності на цьому етапі є здійснення аналізу і ліквідації слабких (уразливих) місць у системі захисту військ (сил) від IПВ противника та проведенні роботи щодо відновлення втрат і нарощування сил і засобів ІПВ, що беруть участь у операції (бойових діях).

Вирішення проблеми інформаційнопсихологічної протидії - завдання непросте, особливо, якщо мати на увазі складну соціальноекономічну та воєнно-політичну обстановку в країні, а також негативні зміни, що відбуваються в якісних характеристиках значної частини особового складу підрозділів 3С України, так і серед цивільно- 
го населення: бездуховність, зневага інтересами держави та суспільства, схильність до користолюбства, пияцтво і наркоманія, зниження інтелектуального рівня тощо. Все це погіршує моральнопсихологічну ситуацію довкола ЗС України та інших військових формувань, а також у самих військових колективах. Проте без прийняття ефективних і рішучих контрзаходів по відношенню до негативної інформаційно-психологічній експансії наслідки можуть бути вельми важкими.

Головним завданням заступника командира підрозділу з МПЗ, що забезпечує надійне управління підрозділами на етапі підготовки та в ході бойових дій, необхідно вважати постійний моніторинг та прогноз психологічної готовності особового складу до виконання завдань за призначенням, при різних варіантах розвитку бойової обстановки.

Для цього йому потрібно знати реальний стан справ у підрозділах, поточний рівень МПС особового складу, точно виявляти сили та засоби інформаційнопсихологічних впливів, які можуть бути використані для здійснення інформаційно-психологічних акцій. Через безперервне, об'єктивне, психологічно доцільне командирське інформування заступник командира 3 морально-психологічного забезпечення повинен роз'яснювати особовому складу мету, завдання, форми і методи психологічних операцій противника, можливості його технічних засобів пропаганди, а також психологічні механізми деформації свідомості військовослужбовця під впливом ворожої пропаганди. Він зобов'язаний забезпечити особовий склад військ (сил) психологічно доцільною інформацією, друкованими періодичними виданнями; організувати перегляд (прослуховування) телевізійних та радіопередач, читання газет, журналів [11]. Враховуючи досвід OОC, командирам та їх заступникам з МПЗ необхідно обмежити та упорядкувати індивідуальне використання воїнами радіоприймачів, мобільних телефонів та інших радіоелектронних пристроїв.

Військовослужбовці мають бути обов'язково попереджені про принципи підривної пропаганди. Досвід ООС, інформаційно-психологічної кампанії в Криму показує, що протидіюча сторона прагне завжди першою повідомляти про всі події, щоб досягти психологічного ефекту «первинності», тобто міцнішого закріплення першої інформації про те, що сталося. У традиціях фахівців ІПВ в інформаційному повідомленні перемішувати правдиву інформацію 3 дезінформацією, підвищувати авторитет своїх акцій за рахунок оперування знайомими прізвищами, назвами міст, вулиць, датами, фактами, шляхом залучення думок відомих осіб (політиків, спортсменів, діячів мистецтва і культури).

Слід ретельно підходити до підбору осіб для роботи на засобах зв'язку і управління. Серед них не повинно бути людей психічно неврівноважених, невитриманих, 3 демонстративною акцентуацією характеру, боязких. Їх повсякденна діяльність має бути узята під строгий контроль безпосередніх начальників. Ці люди повинні добре уявляти, що ті, що оточують, можуть інтерпретувати ті або інші їхні реакції, настрої, вислови як прямий наслідок володіння відповідною інформацією.

Не менш важливим $є$ рішуче припинення командирами будь-яких проявів чуток, поширення панічних настроїв, провокаційних дій, своєчасне знищення листівок та інших дезінформаційних матеріалів противника. Підрозділи, що піддалися деморалізації, повинні надійно ізолюватися від інших до моменту повного відновлення в них дисципліни і порядку.

Для проведення заходів відновлення духовних та фізичних сил особового складу в районах зосередження військ (сил), військових лікувальних закладах, пунктах психологічної реабілітації необхідно забезпечити діяльність мобільних агітаційнопропагандистських груп.

Для надання психологічної допомоги, військовослужбовців, що піддалися негативному ІПВ, необхідно своєчасно направляти до психологів для корекції і реабілітації їх психологічного та морального стану.

Заступник командира з МПЗ має навчати особовий склад методам і прийомам протидії негативному ІПВ та їх адекватного вибору. Навчати військовослужбовців виявляти, розпізнавати ознаки негативного ІПВ та навичкам мобілізації ресурсів свого організму для протидії негативному ІПВ [8].

Основою, на якій можливе створення системи інформаційно-психологічної протидії, мають бути духовно-етичні цінності, що склалися за багатовіковий період розвитку українського суспільства. Такі поняття як патріотизм, Вітчизна, обов'язок, честь не повинні ставитися під сумнів на догоду політичній кон'юнктурі.

Важливою складовою інформаційнопсихологічної протидії $є$ історична самосвідомість військовослужбовців. Значно простіше маніпулювати свідомістю тих людей, які не знають історії свого народу, свого історичного коріння. Тому не лише особисте майбутнє повинне турбувати військовослужбовця, але і майбутнє його країни, в якій його особистісне майбутнє може реалізовуватись. Інакше не буде ні того, ні іншого.

Ідея державного патріотизму, висока історична самосвідомість, гордість за свою військову професію, за приналежність до Збройних Сил, є передумовою формування імунітету до психологічних операцій ворога і мають бути основою, на якій будується вся система інформаційно-психологічної протидії.

Заступник командира підрозділу з МПЗ займається формуванням та утвердженням у свідомості бійців установок та уявлень у відповідності з загальнодержавною ідеологією. Він, по суті, руйнує мі- 
фи та стереотипи, що створюються та нав'язуються ворожою пропагандою, корегує уявлення та розвіює сумніви, що виникають під впливом інформаційнопсихологічних акцій противника. Заступник з МПЗ створює в свідомості солдат образ-стереотип інформації що надає супротивник - як брехливу, агресивну, лицемірну та неправдиву, формує у військовослужбовців і населення свідоме негативне ставлення до ворожих нашій країні і нашому сприйняттю джерел пропаганди і інформації. Установка свідомої недовіри до ворожих джерел ІПВ в умовах бойової обстановки - найважливіша умова ефективності інформаційно-психологічної протидії.

Заступник командира підрозділу з МПЗ є тим бар'єром, який не допускає розповсюдження негативного ІПВ на наші війська і цивільне населення.

Ще одним суттєвим фактором, який має великий вплив на результативність та ефективність заходів інформаційно-психологічної протидії можна визначити особисті та професійні якості військовослужбовців. Формування та розвиток у особового складу професійно необхідних моральнопсихологічних, вольових та бойових якостей, ціннісних орієнтацій є предметом МПЗ.

Інформаційно-психологічна боротьба надзвичайно складний процес, який полягає в оперативному реагуванні на психологічні акції противника, у всебічному врахуванні особливостей психологічних операцій противника та реального МПЗ військ, створенні ефективного бар'єру щодо запобігання проникненню психологічних впливів противника у свідомість особового складу та у постійному відслідковуванні цих процесів, врахуванні закономірностей сприйняття людиною інформації .

Порядок діяльності заступника командира підрозділу з МПЗ щодо організації протидії негативному IПВ противника в загальному вигляді має бути таким:

- виявлення основних джерел негативного ІПВ;

- визначення основного змісту, тез та аргументів офіційної пропаганди, технологій, форм і способів діяльності органів психологічних операцій, державних засобів масової інформації противника;

- оцінка МПС своїх військ і населення в районі застосування військ, можливостей і ступеня негативного ІПВ противника;
- уточнення та усунення факторів бойової, морально-психологічної обстановки, які активно використовуються противником для дезінформації та деморалізації військ і населення;

- прогнозування можливого розвитку бойових дій, сценарію інформаційної (психологічної) операції противника;

- постійне здійснення організаційних, випереджувальних (контрпропагандистських) та силових заходів протидії ІПВ противника.

Реалізація цих умов дозволить підвищити ефективність системи протидії негативному ІПВ на особовий склад ЗС України як в умовах бойових дій, так і у мирний час.

\section{Висновки}

Таким чином, ІПВ містить у собі сукупність способів, видів і методів. Вміле використання даної сукупності дозволяє ефективно впливати на поведінку аудиторії. Вплив на емоційну сферу свідомості об'єкта є важливою складовою інформаційнопсихологічного впливу.

Інформаційно-психологічний вплив здатний підривати основи державності, завдавати серйозної шкоди національним інтересам, ініціювати масові безладдя, страйки та інші акції протесту, дискредитувати органи влади, ускладнювати прийняття владою важливих рішень, створювати напружену атмосферу в державі, паралізувати управління державою в кризових ситуаціях, провокувати політичні, національні, соціальні й релігійні безпорядки, створювати атмосферу бездуховності й аморальності, негативного ставлення до культурної спадщини, дезорганізовувати техносферу, економіку, систему комунікацій, підривати міжнародний авторитет держави, iii співпрацю з іншими країнами.

Ефективне вирішення питань протидії ІПВ противника - це надзвичайно складний, багаторівневий, творчий процес, який вимагає проведення активних організаційних заходів, концентрації попереджувальних контрпропагандистських зусиль, силових методів. Виконання цих завдань можливо лише скоординованими діями командувачів (командирів), штабів, органів 3 морально-психологічного забезпечення у взаємодії (співробітництві) з органами державного управління.

\section{Список літератури}

1. Горбулін В.П. Світова гібридна війна: український фронт: монографія / В.П. Горбулін. - К.: НІСД, 2017. - 496 с.

2. Волошина Н. Вироблення у майбутніх офіцерів імунітету проти негативного інформаційно-психологічного впливу / Н. Волошина, М. Дзюба // Вісник Київського національного університету ім. Тараса Шевченка. - 2013. № 30. - С. 34-37. - Режим доступу: http://nbuv.gov.ua/UJRN/VKNU_vsn_2013_30_11.

3. Турченко Ф.Г. Проект "Новоросія" і новітня російсько-українська війна / Ф.Г. Турченко, Г.Ф. Турченко. - К.: НАН України, 2015. - $166 \mathrm{c.}$

4. Присяжнюк Д.М. Застосування маніпулятивних психотехнологій з боку Росії в ЗМІ України (на прикладі Криму) / Д.М. Присяжнюк // Вісник Київського національного університету ім. Т Шевченка. - 2009. - № 23. - С. 63-66.

5. Баровська А. Інформаційні виклики гібридної війни: контент, канали, механізми протидії / А. Баровська. - К.: НІСД, 2016. - 109 c.

6. Стасюк В.В. Психологічне забезпечення діяльності військ (сил) / В.В. Стасюк. - К.: НУОУ, 2014. - 504 с. 
7. Нарис теорії і практики інформаційно-психологічних операцій / М.Т. Дзюба, Я.М. Жарков, І.О. Ольховой, М.I. Онищук. - К.: ВІТІ НТУУ “КПI”, 2006. - 471 с.

8. Агресія Росії проти України: історичні передумови та сучасні виклики / П.П. Гай-Нижник, Л.Л. Залізняк, І.Й. Краснодемська, Ю.С. Фігурний, О.А. Чирков, Л.В. Чупрій. - К.: МП Леся, 2016. - 586 с.

9. Історія інформаційно-психологічного протиборства / Я.М. Жарков, Л.Ф. Компанцева, В.В. Остроухов, В.М. Петрик, М.М. Присяжнюк, Є.Д. Скулиш. - К.: Науково-видавницький відділ НА СБ України, 2012. - 212 с.

10. Гай-Нижник П.П. Росія проти України (1990-2016рр.): від політики шантажу і примусу до війни на поглинання та спроби знищення / П.П. Гай-Нижник. - К.: МП Леся, 2017. - 332 с.

11. Нарис теорії і практики інформаційно-психологічних операцій / М.Т. Дзюба, Я.М. Жарков, І.О. Ольховой, М.I. Онищук. - К.: ВІТІ НТУУ “КПІ”, 2006. - 471 с.

12. Основи протидії інформаційно-психологічному впливові в особливий період / П.П. Ткачук, В.В. Шемчук, Ю.П. Сальник та ін. - Львів: НАСВ, 2015. - 189 с.

13. Власюк О.С. Національна безпека України: Еволюція проблем внутрішньої політики: Вибр. наук. праці / О.С. Власюк. - К.: НІСД, 2016. -528 с.

14. Остроухов В.В. Основні загрози особистісній безпеці від деструктивних інформаційних впливів. Частина 2. Інформаційно-психологічний вплив / В.В. Остроухов // Сучасний захист інформації. - 2010. - № 4. - С. 4-8. - Режим доступу: http://nbuv.gov.ua/UJRN/szi_2010_4_3.

15. Організація психологічної підготовки особового складу підрозділів Сухопутних військ / За ред. Г.П. Воробйова. - Львів: АСВ, 2012. - 430 с.

16. Структурно-логічна послідовність та принципи організації протидії інформаційно-психологічним впливам 3 боку недружньої держави / В.Ю. Богданович, О.В. Дублян, О.В. Передрій, П. Пацек // Наука і техніка Повітряних Сил Збройних Сил України. - 2019. - № 4(37). - С. 13-19. https://doi.org/10.30748/nitps.2019.37.02.

17. Дубницкий В. Ю. Інтервальне оцінювання кількості учасників масових протестних акцій / В. Ю.Дубницкий, Г.Г. Зубрицкая, А. М. Кобылин // Сучасні інформаційні системи. - 2018. - Т. 2. - № 4. - С. 11-20. https://doi.org/ $10.20998 / 2522-9052.2018 .4 .02$.

\section{References}

1. Horbulin, V.P. (2017), "Svitova hibrydna viina: ukrainskyi front" [World Hybrid War: Ukrainian Front], NISD, Kyiv, 496 p.

2. Voloshyna, N. and Dziuba, M. (2013), "Vyroblennia u maibutnikh ofitseriv imunitetu proty nehatyvnoho informatsiinopsykholohichnoho vplyvu" [Development of future officers' immunity against negative information and psychological influence], Bulletin of Taras Shevchenko National University of Kyiv, No. 30, pp. 34-37, available at: www.nbuv.gov.ua/UJRN/VKNU_vsn_2013 30_11.

3. Turchenko, F.H. and Turchenko, H.F. (2015), "Proekt "Novorosiia" $i$ novitnia rosiisko-ukrainska viina" [The Novorossiya project and the latest Russian-Ukrainian war], NAN Ukrainy, Kyiv, 166 p.

4. Prysiazhniuk, D.M. (2009), "Zastosuvannia manipuliatyvnykh psykhotekhnolohii z boku Rosii v ZMI Ukrainy (na prykladi Krymu)" [Application of manipulative psychotechnologies by Russia in the media of Ukraine (on the example of Crimea)], Bulletin of Taras Shevchenko National University of Kyiv, No. 23, pp. 63-66.

5. Barovska, A. (2016), "Informatsiini vyklyky hibrydnoi viiny: kontent, kanaly, mekhanizmy protydii" [Information challenges of hybrid warfare: content, channels, counteraction mechanisms], NISD, Kyiv, 109 p.

6. Stasiuk, V.V. (2014), "Psykholohichne zabezpechennia diialnosti viisk (syl)" [Psychological support for the activities of troops (forces)], Ivan Chernyakhovsky National University of Defense of Ukraine, Kyiv, $504 \mathrm{p}$.

7. Dziuba, M.T., Zharkov, Ya.M., Olkhovoi, I.O. and Onyshchuk, M.I. (2006), "Narys teorii i praktyky informatsiinopsykholohichnykh operatsii" [Essay on the theory and practice of information and psychological operations], VITI NTUU "KPI", Kyiv, 471 p.

8. Hai-Nyzhnyk, P.P., Zalizniak, L.L., Krasnodemska, I.Y., Fihurnyi, Yu.S., Chyrkov, O.A. and Chuprii, L.V. (2016), "Ahresiia Rosii proty Ukrainy: istorychni peredumovy ta suchasni vyklyky" [Russia's aggression against Ukraine: historical background and current challenges], MP Lesia, Kyiv, 586 p.

9. Zharkov, Ya.M., Kompantseva, L.F., Ostroukhov, V.V., Petryk, V.M., Prysiazhniuk, M.M. and Skulysh, Ye.D. (2012), "Istoriia informatsiino-psykholohichnoho protyborstva" [History of information and psychological confrontation], Naukovovydavnytskyi viddil NA SB Ukrainy, Kyiv, 212 p.

10. Hai-Nyzhnyk, P.P. (2017), "Rosiia proty Ukrainy (1990-2016 rr.): vid polityky shantazhu i prymusu do viiny na pohlynannia ta sproby znyshchennia" [Russia is at war with Ukraine (1990-2016): from a policy of blackmail and coercion to a war of absorption and attempts to destroy], MP Lesia, Kyiv, $332 \mathrm{p}$.

11. Dziuba, M.T., Zharkov, Ya.M., Olkhovoi, I.O. and Onyshchuk, M.I. (2006), "Narys teorii i praktyky informatsiinopsykholohichnykh operatsii" [Essay on the theory and practice of information and psychological operations], VITI NTUU "KPI", Kyiv, 471 p.

12. Tkachuk, P.P., Shemchuk, V.V. and Salnyk, Yu.P. (2015), "Osnovy protydii informatsiino-psykholohichnomu vplyvovi v osoblyvyi period" [Fundamentals of counteracting information and psychological influence in a special period], NASV, Lviv, $189 \mathrm{p}$.

13. Vlasiuk, O.S. (2016), "Natsionalna bezpeka Ukrainy: evoliutsiia problem vnutrishnoi polityky: Vybr. nauk. pratsi" [National Security of Ukraine: Evolution of Domestic Policy Problems], Kyiv, NISD, 528 p.

14. Ostroukhov, V.V. (2010), "Osnovni zahrozy osobystisnii bezpetsi vid destruktyvnykh informatsiinykh vplyviv. Chastyna 2. In-formatsiino-psykholohichnyi vplyv" [The main threats to personal security from destructive information influences. Part 2. Information and psychological impact], Suchasnyi zakhyst informatsii, No. 4, pp. 4-8, available at: www.nbuv.gov.ua/UJRN/szi_2010 43 .

15. Vorobiov, H.P. (2012), "Orhanizatsiia psykholohichnoi pidhotovky osobovoho skladu pidrozdiliv Sukhoputnykh viisk" [Organization of psychological training of personnel of units of the Land Forces], HASV, Lviv, $430 \mathrm{p}$

16. Bohdanovych, V.Yu., Dublian, O.V., Peredrii, O.V. and Patsek, P. (2019), "Strukturno-lohichna poslidovnist ta pryntsypy orhanizatsii protydii informatsiino-psykholohichnym vplyvam z boku nedruzhnoi derzhavy" [Structural-logical 
sequence and principles of organization of counteraction to information-psychological influences by unfriendly state], Science and Technology of the Air Force of Ukraine, No. 4(37), pp. 13-19. https://doi.org/10.30748/nitps.2019.37.02.

17. Dubnitskiy, V., Zubrytska, H. and Kobylin A. (2018), Interval estimation of the number of participants of mass protest actions, Advanced Information Systems, Vol. 2, No. 4, pp. 11-20. https://doi.org/10.20998/2522-9052.2018.4.02.

\section{Відомості про авторів:}

\section{Юзова Ірина Юріївна}

кандидат технічних наук

ТВО начальника Військового коледжу

сержантського складу

Харківського національного університету

Повітряних Сил ім. І. Кожедуба,

Харків, Україна

https://orcid.org/0000-0002-0013-5808

\section{Пацек Петро}

доктор філософії

викладач

Академії військового мистецтва,

Варшава, Польща

https://orcid.org/0000-0002-2182-2316
Information about the authors:

\author{
Iryna Yuzova \\ Candidate of Technical Sciences \\ Acting Chief of the Sergeant Staff \\ Military College \\ of Ivan Kozhedub Kharkiv \\ National Air Force University, \\ Kharkiv, Ukraine \\ https://orcid.org/0000-0002-0013-5808
}

Piotr Pacek

Doctor of Philosophy

Lecturer

of The War Studies University,

Warsaw, Poland

https://orcid.org/0000-0002-2182-2316

\title{
ИНФОРМАЦИОННО-ПСИХОЛОГИЧЕСКОЕ ВОЗДЕЙСТВИЕ ПРОТИВНИКА И ПРОТИВОДЕЙСТВИЕ ЕМУ В УСЛОВИЯХ ВЕДЕНИЯ ГИБРИДНЫХ ВОЙН
}

\author{
И.Ю. Юзова, П. Пацек
}

В статье установлено, что чрезвычайно важное значение приобретают проблемы защиты личного состава Вооруженных Сил Украины и населения от негативного информационно-психологического воздействия противника. Целью статьи является проведение анализа имеющихся проблем защиты личного состава Вооруженных Сил Украины от негативного информационно-психологического воздействия противника и разработка рекомендаций по повышению уровня противодействия информачионно-психологическому воздействию противника в условиях ведения гибридных войн. Установлено, что для сопротивления, сдерживания и защиты как населения Украины, так и личного состава Вооруженных Сил от негативного информационно-психологического воздействия необходимо иметь четкое понимание природы и характера этого конфликта. Приведены сущность, средства, виды и способы информационнопсихологического воздействия. Рассмотрены основные составные задачи защиты войск (сил) от информационнопсихологического воздействия противника.

Ключевые слова: гибридная война, информачионная война, противник, информационно-психологическое воздействие, морально-психологическое обеспечение.

\section{INFORMATION-PSYCHOLOGICAL INFLUENCE OF ENEMIES AND RESPONSE TO IT UNDER CONDITIONS OF HYBRID WAR}

\author{
I. Yuzova, P. Pacek
}

The article establishes that the problems of protection of the personnel of the Armed Forces of Ukraine and the population from the negative informational and psychological influence of the enemy become extremely important. The purpose of the article is to analyze the existing problems of protection of personnel of the Armed Forces of Ukraine from the negative information and psychological influence of the enemy and to develop recommendations for increasing the level of counteraction to information and psychological influence of the enemy in hybrid wars. This influence is a set of specially planned and prepared actions, actions, operations (measures, forms and methods) of influence on civil and military information infrastructure, on individual or public consciousness, moral and psychological condition of personnel of troops (forces) and the population of the enemy to achieve military, political, economic and psychological goals. It is established that in order to resist, deter and protect both the population of Ukraine and the personnel of the Armed Forces from the negative information and psychological impact, it is necessary to have a clear understanding of the nature and nature of this conflict. The essence, means, types and ways of information and psychological influence are given. The main components of the task of protecting troops (forces) from the information and psychological influence of the enemy are considered. In its structure, the protection of troops from the negative information and psychological influence of the enemy has the following stages: forecasting, prevention, disruption and elimination of the consequences of his actions. Conclusions: psychological influence includes a set of methods, types and ways, the skillful use of which can effectively influence the behavior of the audience. Influence on the emotional sphere of the object's consciousness is an important component of information and psychological influence. An effective solution to the problems of counteracting the information and psychological influence of the enemy is an extremely complex, multilevel, creative process that requires active organizational measures, concentration of preventive counter-propaganda efforts, and forceful methods. The direction of further research is a more detailed consideration of the stages of protection of troops from the negative information and psychological influence of the enemy.

Keywords: hybrid warfare, information warfare, adversary, informational and psychological impact, moral and psychological support. 